\title{
Overview of potential geothermal reservoirs in Denmark
}

\section{www.cambridge.org/njg}

\section{Original Article}

Cite this article: Weibel R, Olivarius $M$, Vosgerau H, Mathiesen A, Kristensen L, Nielsen CM, and Nielsen LH. Overview of potential geothermal reservoirs in Denmark. Netherlands Journal of Geosciences, Volume 99, e3. https://doi.org/10.1017/njg.2020.5

Received: 12 April 2019

Revised: 28 November 2019

Accepted: 19 February 2020

\section{Keywords:}

Norwegian-Danish Basin; North German Basin; reservoir sandstones; petrography; diagenesis

Author for correspondence: Rikke Weibel, Email: rwh@geus.dk

\author{
Rikke Weibel $₫$, Mette Olivarius, Henrik Vosgerau, Anders Mathiesen, \\ Lars Kristensen, Carsten M. Nielsen and Lars H. Nielsen
}

GEUS, Geological Survey of Denmark and Greenland, Øster Voldgade 10, 1350 Copenhagen K, Denmark

\begin{abstract}
The Danish onshore subsurface contains very large geothermal resources that have the potential to make a significant contribution to transforming Danish energy consumption toward a more sustainable energy mix. Presently, only a minor fraction of this green energy is exploited in three small plants. The main factors that have hampered and delayed larger-scale deployment are related to uncertainties in the geological models, which inevitably lead to high economic risks that are difficult for smaller district heating companies to mitigate without support from a compensation scheme. To facilitate and stimulate much wider use of the Danish geothermal resources, the Geological Survey of Denmark and Greenland (GEUS) and other research institutes have conducted several regional research projects focusing on the geological and geochemical obstacles with the principal objective of reducing the exploration risks by selecting the best geological reservoirs.

One of the most important geological factors causing uncertainty is the quality of the reservoirs and their ability to produce the expected volume of warm geothermal brine. Thus, great emphasis has been placed on investigating and understanding the relationships between reservoir sandstone, porosity, permeability, petrography, diagenetic processes and alterations related to variable sediment sources, basin entry points, depositional systems and climate, burial and thermal history. Mesozoic sandstones comprise the most important geothermal reservoirs in Denmark. Details concerning the reservoir quality are compiled and compared for the Lower Triassic Bunter Sandstone, Triassic Skagerrak, Upper Triassic - Lower Jurassic Gassum and Middle Jurassic Haldager Sand formations. The Bunter Sandstone Formation contains extensive aeolian and more confined fluvial sandstones with high porosity and permeability. However, highly saline formation water could be unfavourable. The Skagerrak Formation comprises well-sorted braided stream sandstones in the centre of the basin, and is otherwise characterised by muddy sandstones and alluvial fan conglomerates. An immature mineralogical composition has caused intensive diagenetic changes in the deepest buried parts of the basin. The Gassum Formation consists of shoreface, fluvial and estuarine sandstones interbedded with marine and lacustrine mudstones. In the upper part of the formation, the sandstone beds pinch out into mudstones towards the basin centre. Pervasive siderite- and calcite cement occurs locally in shallowly buried sandstones, and with burial depth the maximum abundances of quartz and ankerite cement increase. Sandstones of shallow burial represent excellent reservoirs. The relatively coarse grain size of the Haldager Sand Formation results in high porosity and permeability even at deep burial, so the formation comprises a high-quality geothermal reservoir.

Substantial progress has been made, and a well-established regional geological model combined with reservoir quality is now available for areas with cored wells. This has enabled an improved estimation of reservoir quality between wells for exploration of geothermal reservoirs.
\end{abstract}

\section{Introduction}

Utilisation of geothermal energy has been part of the Danish national energy strategy for decades. In the late 1970 s and early 80 s, geothermal energy was seen as a means to reduce dependency on imported fossil fuels. With increased awareness of climate changes related to the use of fossil fuels, geothermal energy is now seen as an indispensable source of energy for heating a large fraction of the Danish households connected by existing district heating systems.

The first geothermal test in Denmark was conducted in 1976, when the Oddesund-1 well drilled by DUC (Danish Underground Consortium) tested good water flow from a narrow zone in the Gassum Formation at $2000 \mathrm{~m}$. During the following years, DONG (Danish Oil and Natural Gas) attempted to develop the business case and was granted a nationwide licence in 1983. In 1979-1982, the two deep wells Aars-1 and Farsø-1 were drilled in the Himmerland Graben (Fig. 1), where the Upper Triassic-Lower Jurassic Gassum Formation is deeply buried at $\sim 3 \mathrm{~km}$, as high temperatures were targeted. However, the water flow was insufficient due to diagenetic alterations in the encountered reservoir sandstones. Still targeting high 


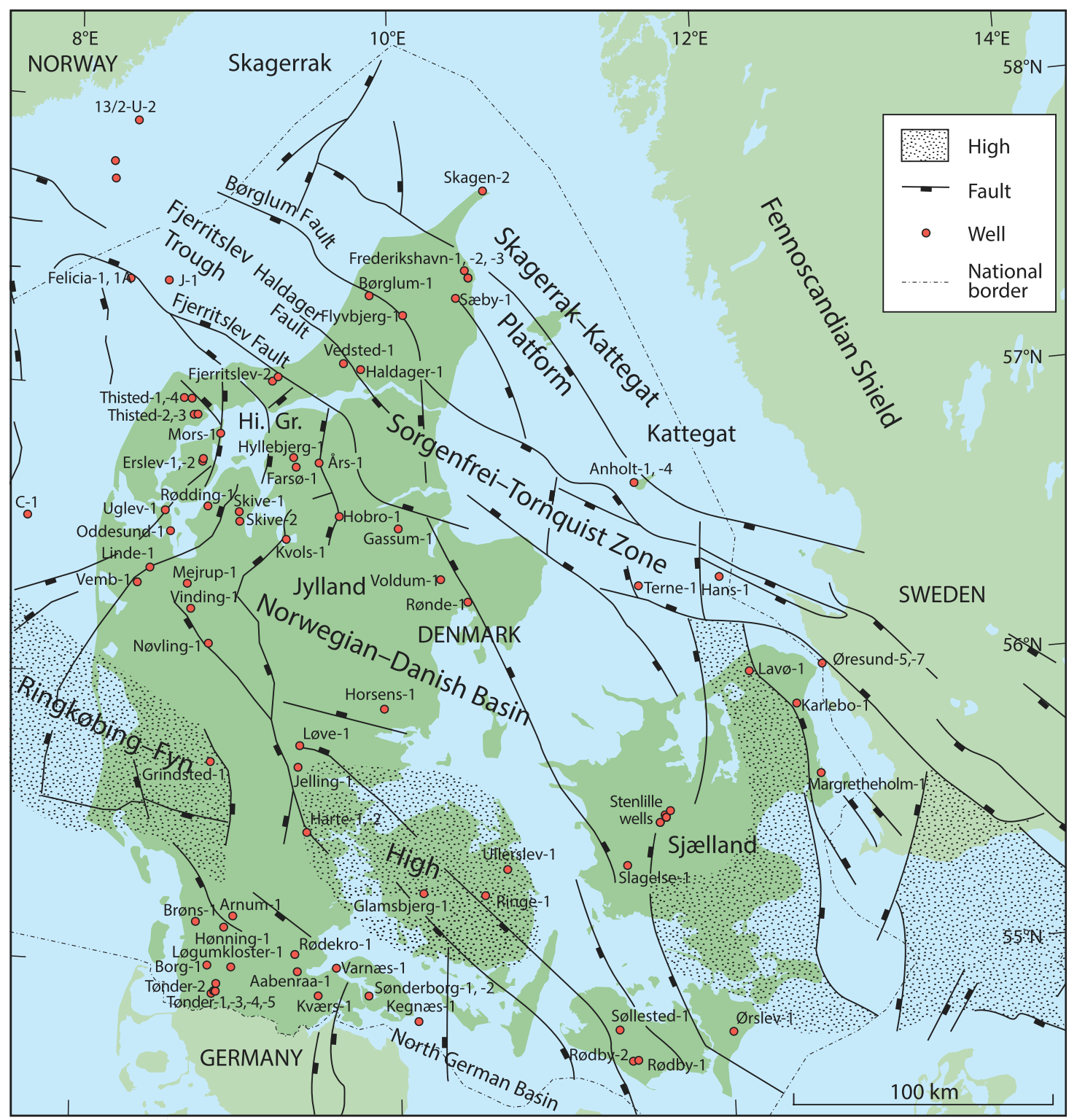

Fig. 1. Map showing the principal structural elements of the eastern parts of the Norwegian-Danish Basin and the northern part of the North German Basin.

temperature, the Thisted-2 well was drilled in 1982 to test the Skagerrak Formation. Sandstones were encountered, but repeated flow tests showed decreasing flow rates presumably owing to abundant fibrous illite (Weibel et al., 2017b) rather than migration of fines, which was observed in the Gassum and Haldager Sand formations (Priisholm et al., 1987). Instead, the well was completed with production from the shallower Gassum Formation at c. $1250 \mathrm{~m}$, and in 1984 the Thisted geothermal plant was commissioned as the first geothermal plant in Denmark. This plant has produced geothermal heat since then without major challenges, and recently the capacity was expanded with a new injection well.

After a period when DONG was focused on North Sea-related activities, a renewed campaign assisted by GEUS was initiated with financial support from the European Union. This resulted in the Margretheholm geothermal plant, which was inaugurated in 2006 with production from sandstones at $c .2700 \mathrm{~m}$ in the Lower Triassic Bunter Sandstone Formation. Later, in 2013 the third geothermal plant in Denmark, the Sønderborg plant, started production from sandstones at c.1250 $\mathrm{m}$ in the Upper Triassic-Lower Jurassic Gassum Formation (Røgen et al., 2015; Poulsen et al., 2019).

In parallel with the limited activities of DONG, GEUS together with the universities of Aarhus and Copenhagen conducted several research projects focusing on stimulating the exploitation of the geothermal resource by reducing the exploration risks. The principal geological risk was related to insufficient geological models predicting presence, quality, production capacity and temperature of the potential geothermal reservoirs. The geological uncertainty, which causes high economic risks, has halted the development of geothermal energy, as it is difficult for small, local district heating companies to accommodate such risks without a compensation plan. Therefore, geothermal research at GEUS has been directed toward the establishment of geological models of the subsurface in order to guide and direct exploration efforts toward the most promising areas, avoiding costly wells in high-risk areas (Nielsen et al., 2004; Mathiesen et al., 2010). A cornerstone has been a major mapping campaign that thoroughly evaluated seismic 
reflection surveys and well data acquired during former hydrocarbon and subordinate gas storage and geothermal exploration activities. The campaign has reduced the exploration risks significantly and has shown that several sandstone-rich formations in the Norwegian-Danish Basin and the North German Basin have substantial geothermal potential (Vosgerau et al., 2016, 2017). Better geological models, an increasing need for a sustainable energy supply and adjustments of the taxation regime have stimulated interest in exploring and utilising geothermal energy, and during the last few years several companies have applied for licences at the Danish Energy Agency.

The geographical coverage and quality of the data vary considerably (Vosgerau et al., 2016). Reliable information on structural development, hydraulic and thermal conditions of the subsurface is fundamental for the exploration and exploitation of geothermal energy. By interpretation and integration of all available seismic reflection data and exploration well data, GEUS has constructed a regional 3D geological model, which outlines the structuralstratigraphical evolution from the Late Permian through Late Cretaceous of the Danish onshore area. It also illustrates the lateral extent of the lithostratigraphic units known to contain geothermal reservoir sandstones, and the location of major faults and salt structures. The resulting maps are accessible from a user-friendly WebGIS portal, as are a number of seismic cross-sections and an interactive 3D tool that exemplify the structural distribution of the onshore subsurface units (Vosgerau et al., 2016). Besides mapping of extent and thicknesses, evaluation of reservoir quality involved compilation of porosity and permeability measurements from cored wells and petrographical investigations to reveal important factors affecting reservoir quality. These investigations revealed a high potential of the Lower Triassic Bunter Sandstone Formation in the North German Basin (Olivarius et al., 2015). Porosities and permeabilities varying prominently with grain size and burial depth were documented for the Triassic Skagerrak and Gassum formations (Weibel et al., 2017a,b). This paper presents the first comparison of their reservoir quality that also includes the Haldager Sand Formation, which shows promising qualities.

\section{Geological background}

The subsurface of the Danish onshore area consists of three principal structural units: the eastern part of the Norwegian-Danish Basin, the northern part of the North German Basin and the Ringkøbing-Fyn High separating the two basins (Fig. 1). The high consists of shallow basement blocks, where the thin Mesozoic sedimentary cover mainly comprises erosional remnants of Triassic sedimentary rocks and Upper Cretaceous Chalk with a low geothermal potential. In contrast, the two basins host very large geothermal resources and several potential reservoirs. The basins are classic low-enthalpy sedimentary basins formed by crustal thinning followed by long-term thermal subsidence and infilling by a variety of deposits (Vejbæk, 1989; Michelsen \& Nielsen, 1991; Nielsen \& Japsen, 1991; Michelsen et al., 2003). Although geothermal potential may exist in the underlying Palaeozoic rocks and in the rift sections of the basins, which in places contain Upper Carboniferous-Lower Permian clastic prisms, the principal potential is within the Mesozoic post-rift succession (Michelsen \& Nielsen, 1993; Nielsen et al., 2004; Mathiesen et al., 2010; Vosgerau et al., 2016). The sedimentary successions may be up to $9 \mathrm{~km}$ thick in the central parts of the Norwegian-Danish Basin, but they thin dramatically toward the northern,

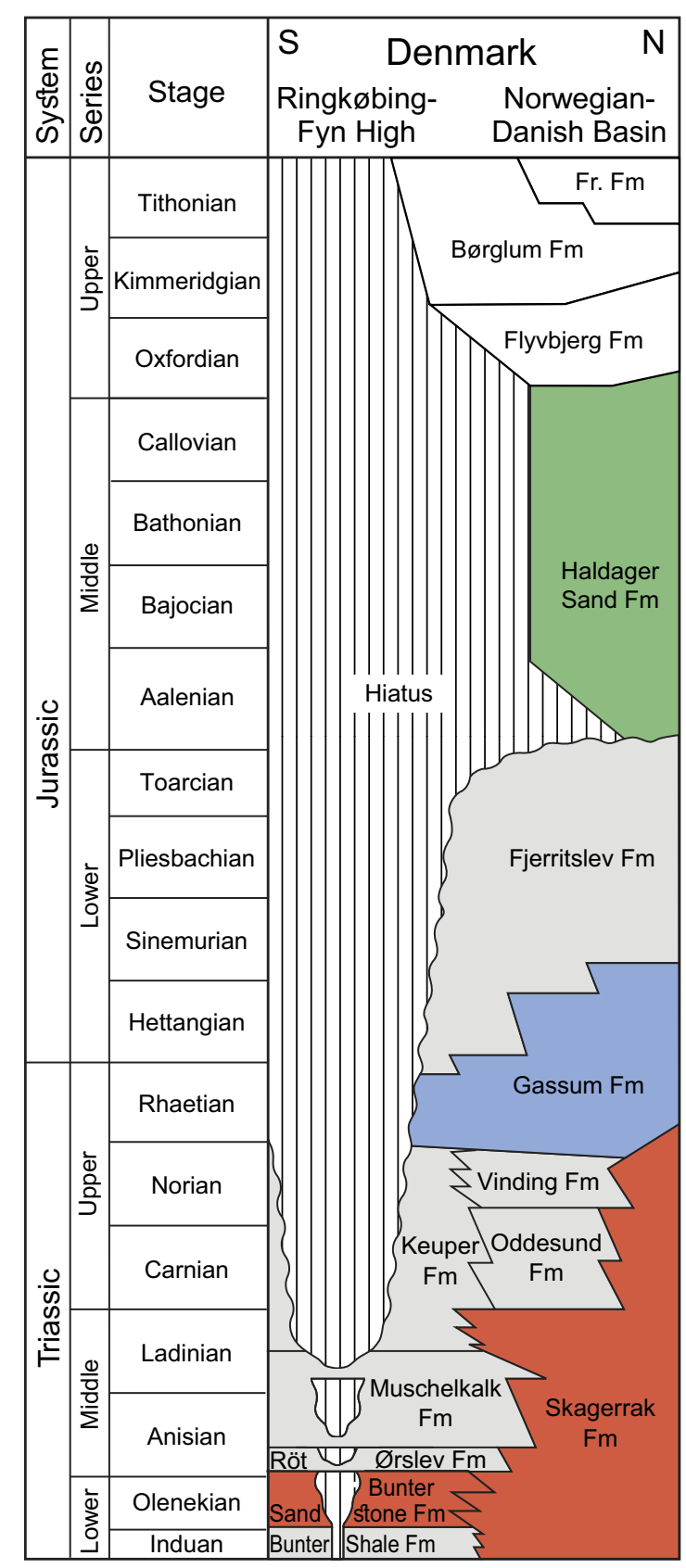

Fig. 2. Stratigraphic scheme illustrating a schematic S-N cross-section of the Triassic-Jurassic succession of the eastern part of the Norwegian-Danish Basin, the Ringkøbing-Fyn High and the northernmost rim of the North German Basin. The four lithostratigraphic units with geothermal potential described here are highlighted with colours. Modified after Bertelsen (1980), Michelsen and Clausen (2002), Michelsen et al. (2003) and Nielsen (2003).

northeastern and southern basin margins due to thinner lithostratigraphic units and pronounced hiatuses caused by erosion during uplift events (Fig. 2; Britze \& Japsen, 1991; Japsen \& Langtofte, 1991; Michelsen et al., 2003; Nielsen, 2003; Japsen et al., 2007). In the Danish part of the North German Basin, the geothermal reservoirs within the Upper Triassic-Cretaceous are missing or poorly preserved due to uplift and erosion, and the reservoirs suffer in places from very saline brines (Laier \& Nielsen, 1989; Hjuler et al., 2019). Further complicating factors in both basins include major faults as well as significant salt structures that displace the 
reservoir-bearing formations and interrupt lateral continuity of the reservoirs, thus imposing large geological risks.

In addition to the risk of limited reservoir continuity, the quality of the various reservoir sandstones expressed by porosity and permeability is a major challenge as the effective permeability determines the flow rates that can be obtained in the production and injection wells. With the objective of gaining capability to predict reservoir productivity prior to the drilling of expensive exploration wells, GEUS has investigated the petrography of the reservoir sandstones and compared it with porosity and permeability in order to understand the variations related to sediment source areas, entry points and the diagenetic alterations associated with burial depths, temperature, geochemical composition of brines, as well as late uplift (Kristensen et al., 2016; Olivarius \& Nielsen, 2016; Olivarius et al., 2017; Weibel et al., 2017a,b). Based on the detailed petrographic database obtained, GEUS has initiated advanced diagenesis modelling with the ultimate goal of predicting reservoir quality in undrilled exploration areas (e.g. Nielsen et al., 2019). Comparison of the mineralogical composition of specific reservoirs with formation water composition has been used to geochemically predict potential risk of scaling (Holmslykke et al., 2019; Kazmierczak et al., 2019). Even though geochemical modelling indicates a risk of barite precipitation, corrosion and precipitation of e.g. lead proved to be a larger problem at the Margretheholm Geothermal Plant (Olivarius et al., 2019).

Another important factor for geothermal reservoirs is the temperature of the brines. Research at the University of Aarhus in conjunction with GEUS has shown that the temperature gradient is typically $25-30^{\circ} \mathrm{C} \mathrm{km}^{-1}$ without pronounced temperature anomalies. The temperature distribution is fairly well understood and the observed variations in temperature gradients are mainly owing to differences in thermal conductivity of the geological strata (Fuchs et al., 2015; Fuchs \& Balling, 2016; Poulsen et al., 2017; Fuchs et al., 2020). Simulations of the production lifetime of a geothermal plant show that it can take many decades before a notable temperature drop can be detected if production and injection wells are separated more than $1000 \mathrm{~m}$ in reservoirs with transmissibilities in the $10+D m$ range and operated at rates of $100-200 \mathrm{~m}^{3} \mathrm{~h}^{-1}$ (Poulsen et al., 2017).

\section{Methods}

Petrographical investigations are based on optical microscopy and scanning electron microscopy. The polished thin sections were impregnated with blue epoxy, for easy identification of porosity. Modal composition was obtained by point-counting at least 500 grains, excluding pores, in thin sections. The thin sections were etched and stained with sodium cobaltinitrite in order to ensure fast identification of K-feldspar during point counting. Grain size and the degree of sorting were evaluated in each thin section. The Wentworth classification scheme provided the grain-size nomenclature (Wentworth, 1922) while sorting was estimated petrographically using the sorting comparators of Longiaru (1987), based on the sorting classes of Folk (1966). The sorting classes are defined for eight relative phi classes that range from very well to poorly sorted.

Supplementary studies of crystal morphologies and paragenetic relationships were performed on gold-coated rock chips mounted on stubs and on carbon-coated polished thin sections using a Phillips XL 40 scanning electron microscope using a secondary electron detector (SE) or back-scatter electron detector (BSE).
Energy-dispersive X-ray spectroscopy (EDS) analysis of detrital grains in thin sections verified the identification of feldspar during point counting. The electron beam was generated by a tungsten filament operating at $17 \mathrm{kV}$ and $50-60 \mu \mathrm{A}$.

Porosity and permeability were measured on well core plugs according to the API RP-40 standard (American Petroleum Institute, 1998). He-porosity was measured at unconfined conditions. Gas permeability was measured at a confining pressure of $\sim 2.8 \mathrm{MPa}\left(400 \mathrm{psi}\right.$ ), and at a mean $\mathrm{N}_{2}$ gas pressure of $\sim 1.5 \mathrm{bar}$ (bar absolute $)=0.15 \mathrm{MPa}$. Permeabilities below $0.05 \mathrm{mD}$ were not measured or were measured using a bubble flowmeter.

\section{Geothermal reservoirs onshore Denmark}

The geological analyses of the Danish onshore areas have indicated the presence of several potential reservoirs including the Lower Triassic Bunter Sandstone Formation, the Triassic Skagerrak Formation, the Upper Triassic-Lower Jurassic Gassum Formation, the Middle Jurassic Haldager Sand Formation, the Upper Jurassic Flyvbjerg Formation and the Upper Jurassic-Lower Cretaceous Frederikshavn Formation. In addition to these formal lithostratigraphic units, sandstones with reservoir quality are present in some areas, interbedded with the Lower Jurassic Fjerritslev Formation mudstones and within the Lower Cretaceous mudstones. In the following, the four formations with the largest geothermal potential are described (the Bunter Sandstone, Skagerrak, Gassum and Haldager Sand formations).

\section{Bunter Sandstone Formation}

The Bunter Sandstone Formation was deposited during the Early Triassic in the North German Basin and in the southern part of the Norwegian-Danish Basin. The thickness varies greatly but is generally less than $c .300 \mathrm{~m}$ in the Danish part of the North German Basin. In the southern part of the Norwegian-Danish Basin, the formation northwards grades into the time-equivalent lower part of the Skagerrak Formation; however, the nature and position of this transition is poorly known. Cored intervals of the formation are present at burial depths of $1.4-1.9 \mathrm{~km}$ and have been buried to maximum depths of c.1.7-2.1 km prior to Neogene exhumation. The sandstones of the Bunter Sandstone Formation were deposited at the base of four depositional cycles that each grade upwards into lacustrine/playa mudstone. These are named the Volpriehausen, Detfurth, Hardegsen and Solling members corresponding to the German subdivision of the Middle Buntsandstein, of which the Detfurth and Hardegsen members are of small extent and thickness in the Danish area since they were deeply eroded prior to deposition of the Solling Member (Geluk \& Röhling, 1997; Michelsen \& Clausen, 2002). Consequently, only the Volpriehausen and Solling members contain adequate geothermal reservoir resources to be considered here. The sandstones of the Volpriehausen Member are aeolian sand sheet deposits interbedded with ephemeral fluvial deposits towards the top of the succession. The sandstones of the Solling Member were deposited during increased humidity and comprise primarily ephemeral fluvial deposits (Clemmensen, 1985). The sediment was supplied by northward aeolian transport from the Variscan belt and by southward fluvial and alluvial transport from the Ringkøbing-Fyn High and Fennoscandian Shield (Olivarius et al., 2017). Individual sandstone-dominated intervals are $30-50 \mathrm{~m}$ thick, and some of the 
intervals are considered to have a regional extent although not mapped in detail (Olivarius et al., 2017).

The sandstones are mostly fine-grained and well-sorted, and the aeolian sand tends to be very well-sorted. In general, the sandstones are pale red to reddish brown and contain greenish grey reduction spots and light pinkish grey anhydrite nodules in some intervals. The sandstones are arkosic to subarkosic, according to the classification of McBride (1963), with dominance of quartz and abundant feldspar. Mica, rock fragments and heavy minerals occur in small amounts (Fig. 3). Calcitic ooids are primarily present in the aeolian deposits, which suggests aeolian transport from their place of formation, i.e. shore of playa lake. Intraclasts and detritral clays are present only in the ephemeral fluvial and playa lake deposits. Heavy minerals comprise zircon, rutile, hematite, ilmenite, magnetite and titanomagnetite (Weibel \& Friis, 2004).

The authigenic phases comprise an average of $17-31 \%$ of the rock volume in each investigated well, of which calcite, dolomite and anhydrite cement are dominant. Anhydrite is found in amounts of up to $35 \%$, but the content is highly variable, being lowest in the aeolian sandstones and highest in the fluvial sandstones. The anhydrite cement is patchy pore-filling and partially displacive. Calcite occurs mainly as patchy cement, and dolomite rhombs are scattered in all the sedimentary rocks. Pervasive carbonate cementation of up to $18 \%$ occurs mostly in thin-bedded clayey sandstones. Minor amounts of quartz overgrowths (Fig. 4), feldspar overgrowths, analcime, anatase, barite and pore-filling clays have formed in the sandstones. The pore-filling clays are mainly illite, chlorite and small amounts of mixed-layer illite/smectite (Weibel \& Friis, 2004). Halite occurs as a cement and not only an artefact after dried formation water (Laier \& Nielsen, 1989; Weibel \& Friis, 2004; Olivarius et al., 2015). Red coatings of goethite and hematite have formed on the grains in most samples (Weibel \& Friis, 2004).

The core analyses show that several sandstones have porosity of 15-35\% and a corresponding permeability of 10-3000 mD (Fig. 5). The permeability varies with grain size such that a mediumgrained sandstone with a porosity of $15 \%$ can have a permeability of $1000 \mathrm{mD}$ similarly to a fine-grained sandstone with a porosity of $25 \%$. Some of the aeolian sands are unconsolidated, so their reservoir properties could not be measured. The porosity and permeability of aeolian sand in Figure 5 are instead estimated from their grain size and degree of sorting based on Beard \& Weyl (1973).

\section{Skagerrak Formation}

The Skagerrak Formation is present in the Norwegian-Danish Basin where it locally occurs with thicknesses up to $5000 \mathrm{~m}$ (Bertelsen, 1980; Liboriussen et al., 1987). Cored intervals of the formation are present at variable depths of $1.2-5.0 \mathrm{~km}$ and have been buried to maximum depths of c.1.8-5.7 km prior to Neogene exhumation. The Skagerrak Formation was deposited in alluvial fans along the Fennoscandian Border Zone and continued into braided streams in the more distal part of the basin towards the southwest (Pedersen \& Andersen, 1980; Olsen, 1988; Weibel et al., 2017b). In places, aeolian deposits have been identified, hence aeolian reworking of the fluvial deposits may have been an important process (Pedersen \& Andersen, 1980). The lower part of the formation is time-equivalent to the Bunter Shale Formation and the Bunter Sandstone Formation in the central part of the basin, and the mid-upper part is contemporaneous with the Röt, Ørslev, Muschelkalk and Keuper formations in the southwestern part of the basin and the Oddesund and Vinding formations in the more northerly part of the basin (Fig. 2; Weibel et al., 2017b).

Onshore wells penetrating the Skagerrak Formation are limited but show that individual sandstone-dominated intervals may exceed $200 \mathrm{~m}$, where sandstones from braided streams aggrade. Some of the intervals probably have a regional extent but have not been mapped in detail. The Skagerrak Formation consists primarily of clayey sandstones, hence the reservoir permeability is generally quite low. Thus, despite continuous sandstone intervals, the reservoir quality of most of the sandstone succession is low.

The alluvial fan deposits comprise moderately to poorly sorted conglomerates, fine-grained sandstones or siltstones, whereas claypoor braided stream sandstones are well-sorted and fine- to medium-grained. The sandstones are dominated by subarkoses, lithic subarkoses, arkoses and smaller contents of sublitharenite, feldspatic litharenite and litharenite according to the classification of McBride (1963). The degree of weathering was limited in the arid to semi-arid climate that prevailed during deposition of the formation, hence the initial detrital composition is mineralogically immature. Ca-rich plagioclase and albite are common in the alluvial fan deposits, whereas further from the sediment source, in the braided stream deposits, K-feldspar dominates the feldspar group (Fig. 3). Rock fragments consist mainly of igneous and to a lesser extent of metamorphic rock fragments, though locally of common volcanic rock fragments (Weibel et al., 2017b). Mica is present in small amounts in all samples. Heavy minerals comprise zircon, rutile, ilmenite, hematite and titanomagnetite.

The cementing phases comprise on average 9-26\% of the rock volume in each investigated well, of which the carbonate cement is typically the most extensive. Authigenic carbonate comprises dolomite as rhombs or pore-filling poikilotopic cement and to a lesser extent calcite cement. Some of the carbonate cement is replacive, as indicated by their abundance higher than the initial pore volume. Calcrete cement occurs only in the shallowly buried alluvial fan deposits. Clay minerals occur as tangentially orientated coatings on detrital grain in the shallowly buried parts of the Skagerrak Formation, though as radiating pore-lining clay coatings in the deeply buried parts. The dominant clay mineral in the Skagerrak Formation changes from smectite and randomly orientated mixed-layer smectite/illite in the shallowly buried parts to ordered mixed-layer illite/smectite in the deeply buried parts (Weibel, 1999; Weibel et al., 2017b). Honeycomb-textured illite coatings support the transformation of smectite- to illitedominated clay coatings. Authigenic quartz occurs as syntaxial prismatic outgrowths or pore-filling overgrowths depending on thickness of the iron-oxide/hydroxide and clay coatings (Fig. 4). Red coatings of iron-oxide/hydroxides provide the prevailing red colour of the Skagerrak Formation. Goethite is the dominant iron-oxide/hydroxide at shallow burial, whereas hematite dominates in the red coatings with increasing burial depth (Weibel, 1999; Weibel \& Groberty, 1999). Authigenic anatase occurs as discrete crystals in the pores close to altered Fe-Ti oxides and as a part of leucoxene-replacement of $\mathrm{Fe}-\mathrm{Ti}$ oxides. Authigenic K-feldspar is common as overgrowths on detrital feldspar grains and as crystals precipitating on remnants of partly dissolved feldspar grains. Anhydrite is in the Skagerrak Formation, contrary to the Bunter Sandstone Formation, a rare very late pore-filling cement.

Porosity and permeability is highest for shallowly buried braided river sandstones. These fluvial sandstones show a clear 

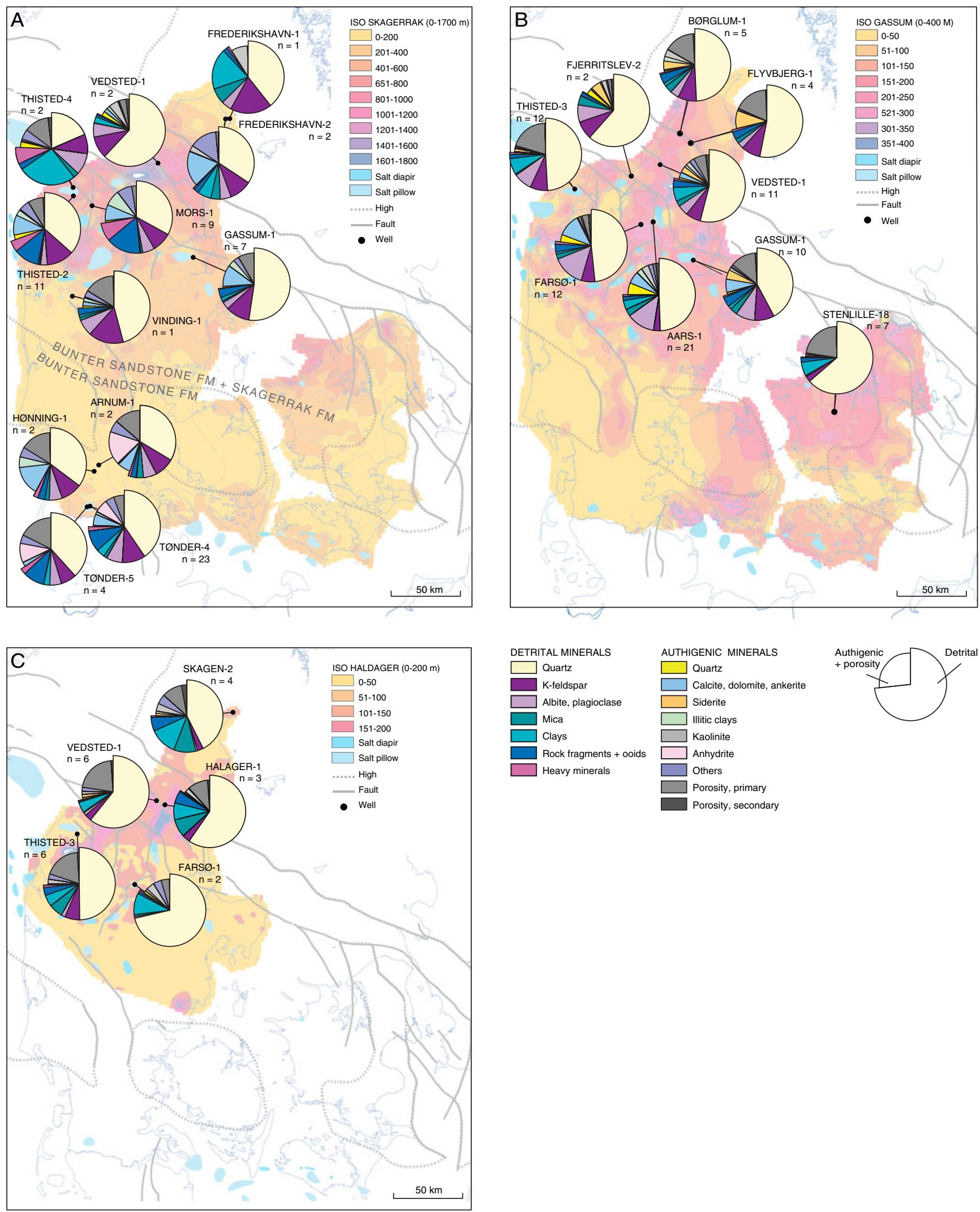

Fig. 3. Three pie diagrams showing the distribution of detrital components and cementing phases of the Bunter Sandstone and Skagerrak formations (A), Gassum (B) and

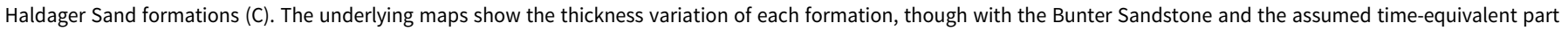
of the Skagerrak formations combined. 

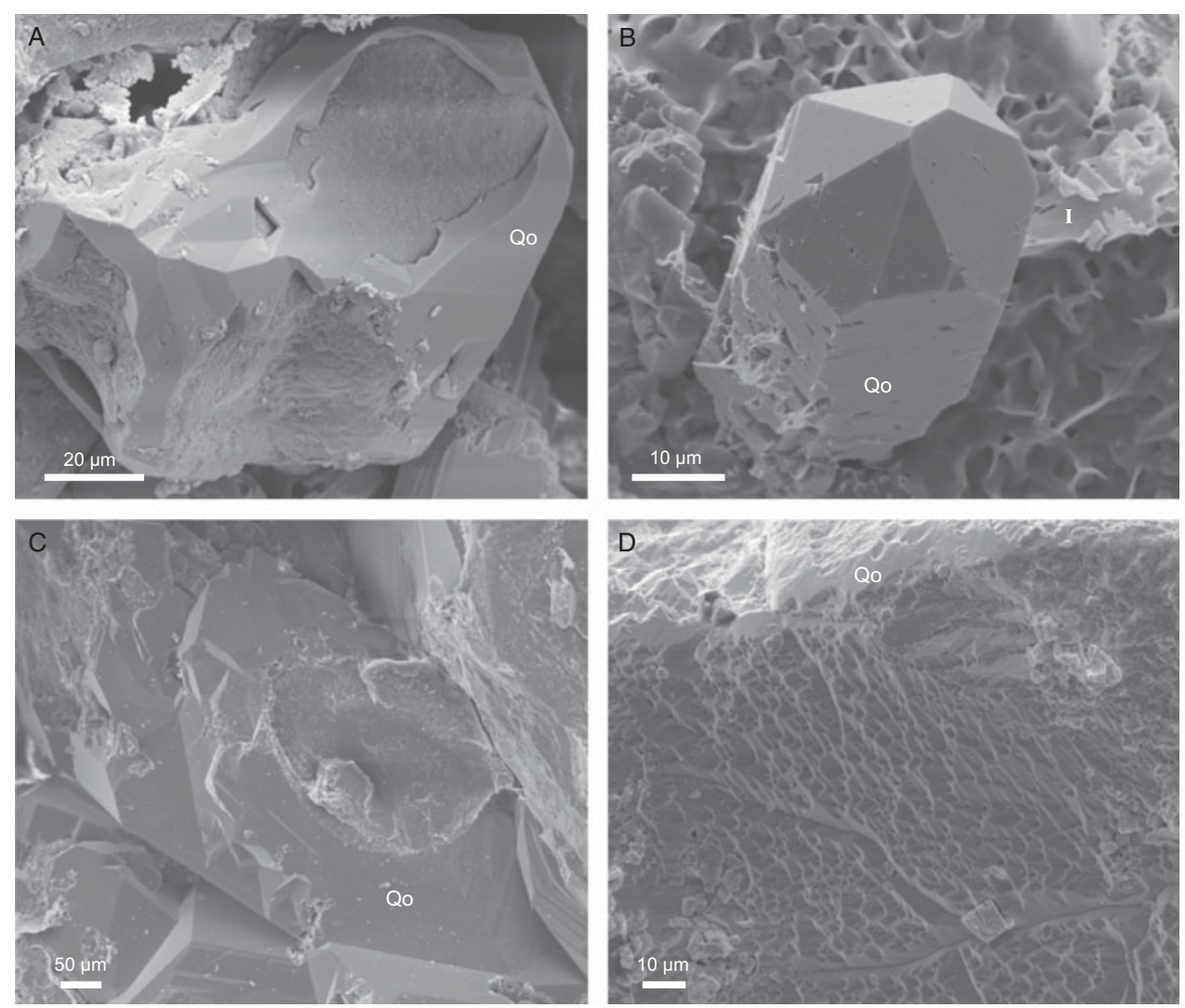

Fig. 4. Different types of quartz overgrowth characteristic of the different formations as secondary electron imaging by scanning electron microscope. (A) Limited quartz overgrowth (Qo) due to abundant red coatings, Bunter Sandstone Formation, Tønder-4, 1663.27 m. (B) Quartz outgrowth (Qo) due to thick illitic coatings (I), Skagerrak Formation, Thisted-2, $2919.33 \mathrm{~m}$. (C) Large quartz overgrowth (Qo) (macroquartz), Gassum Formation, Farsø-1, $2871.64 \mathrm{~m}$. (D) Limited quartz overgrowths (Qo) as quartz mountains (terminology of Weibel et al., 2010), Vedsted-1, Haldager Sand Formation, $1155.47 \mathrm{~m}$. variation in permeability with grain size; the coarsest-grained sandstones generally have a higher permeability at similar porosity than medium-, fine- or very fine-grained sandstones. The alluvial fan deposits typically have lower porosity-permeability trend than the coarse- and medium-grained braided stream sandstones despite a generally shallower burial depth (Weibel et al., 2017b). The influence of diagenesis, in particular illite, on permeability is illustrated by the group of sandstones having a comparable low permeability from the Thisted-2 well, where fibrous illite coatings are ubiquitous (Fig. 5). Quartz cement and dolomite/calcite cement cause a reduction of both porosity and permeability in the deeply buried sandstones.

\section{Gassum Formation}

The Late Triassic to Early Jurassic Gassum Formation is widely distributed in the Norwegian-Danish Basin and partly in the Danish part of the North German Basin with a general thickness of 50-150 $\mathrm{m}$ and locally, in the Sorgenfrei-Tornquist Zone, it may be more than $300 \mathrm{~m}$ thick (Nielsen \& Japsen, 1991; Nielsen, 2003). However, locally it may be missing due to uplift and erosion related to vertical salt movements and it is generally lacking over the Ringkøbing-Fyn High and occurs with reduced thicknesses on the Skagerrak-Kattegat Platform, though it is patchily preserved just south of the high (Nielsen \& Japsen, 1991; Nielsen, 2003). Cored intervals of the formation are present at variable depths of $0.6-3.4 \mathrm{~km}$ and have been buried to maximum depths of c.1.4-3.8 km prior to Neogene exhumation. The depositional environment was interpreted as deltaic by Larsen (1966), but subsequent detailed sedimentological investigations of a large number of cores and well-logs from new wells enabled a subdivision into six parallic and marine facies associations (Hamberg \& Nielsen, 2000; Nielsen, 2003). The deposition occurred in a shallow marine embayment under the influence of repeated relative sealevel changes causing deposition of regressive shoreface sand and fluvial-estuarine sand encased in marine, lagoonal and lacustrine mudstones. Significant incision occurred during sea-level falls, and deeply incised valleys were locally formed and subsequently filled with estuarine deposits during the following sealevel rise. The sedimentary rocks are grouped into a number of depositional sequences, which shows that the deposition of sandstones through time gradually became limited to the northeastern basin margin (Nielsen, 2003).

Sandstone-dominated intervals in the lower part of the formation extend over the entire Norwegian-Danish Basin, whereas those from the upper part of the formations pinch out into mudstones in the central part of the basin (Nielsen, 2003). The Gassum Formation, characteristically 150-200 m thick in the NorwegianDanish Basin, may have 5 to 20 sandstone layers. The thickness of the individual sandstone-dominated intervals varies between 5 and $60 \mathrm{~m}$, and about half of the gross sand equals reservoir-quality sandstone having high porosity and permeability.

The Gassum Formation comprises light grey, well-sorted fineto medium-grained sandstones and common heterolithic intervals, which are non-reservoir. The sandstones are classified as subarkoses and arkoses (McBride, 1963). Quartz is mainly monocrystalline with subordinate polycrystalline grains. Feldspar abundance varies across the basin, with feldspar relatively more common in the northwestern part than in the eastern part (Fig. 3). Within the feldspar group, K-feldspar is more common in the shallowly buried parts, whereas albite increases in abundance with burial depth mainly due to albitisation (Friis, 1987; Weibel et al., 2017a,b). Rock fragments are generally rare. Mica, mainly muscovite, occurs in all samples. Heavy minerals comprise rutile, zircon, epidote, garnet and remnants after ilmenite and titanomagnetite. 


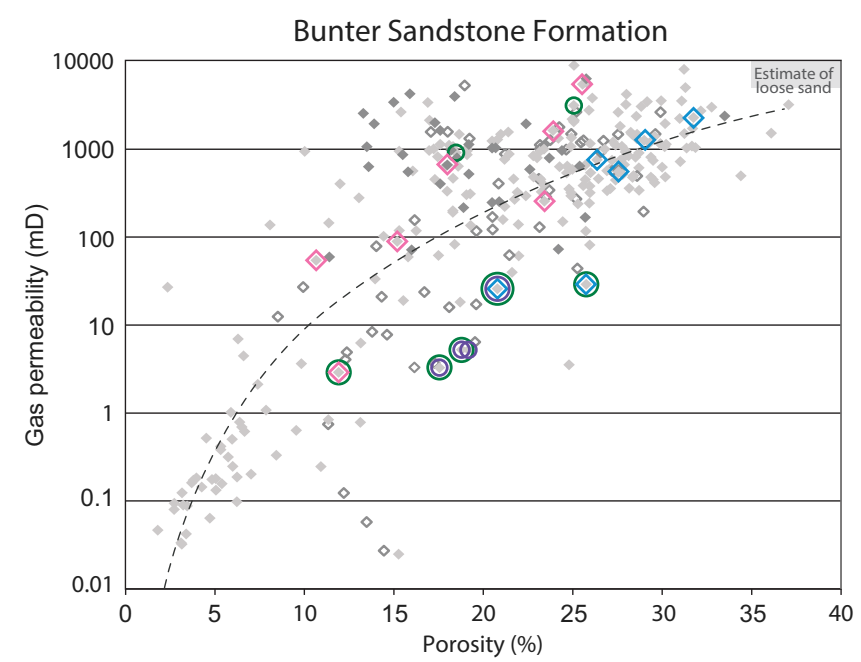

Gassum Formation

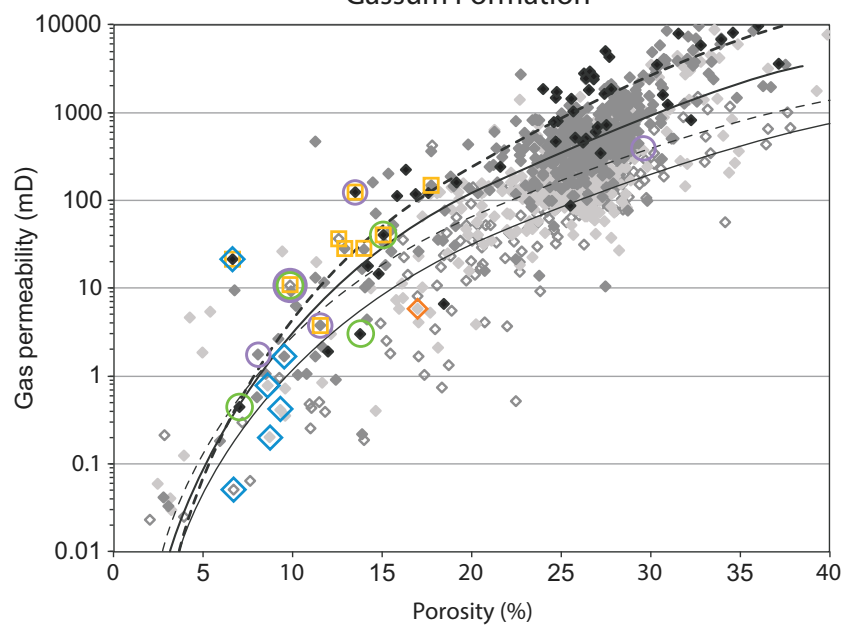

Skagerrak Formation

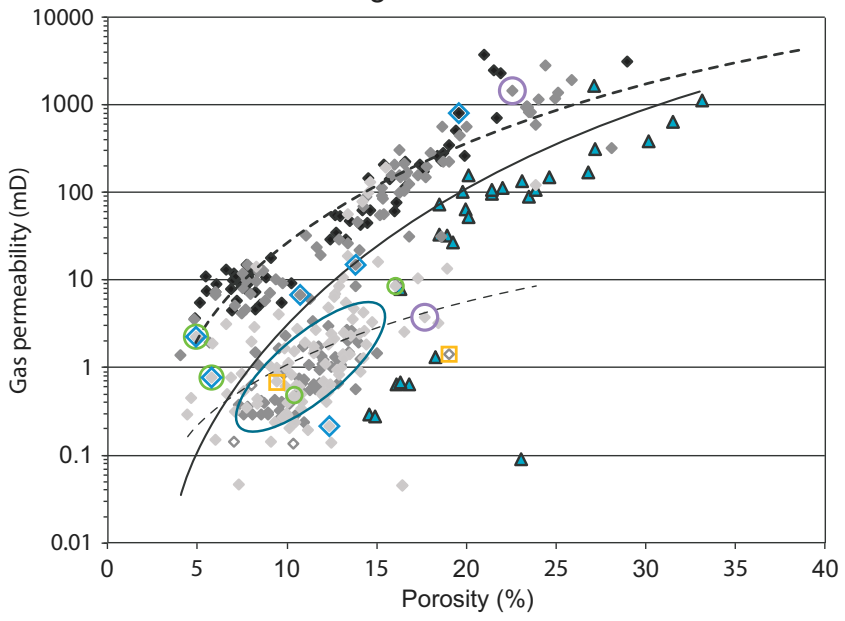

Haldager Sand Formation

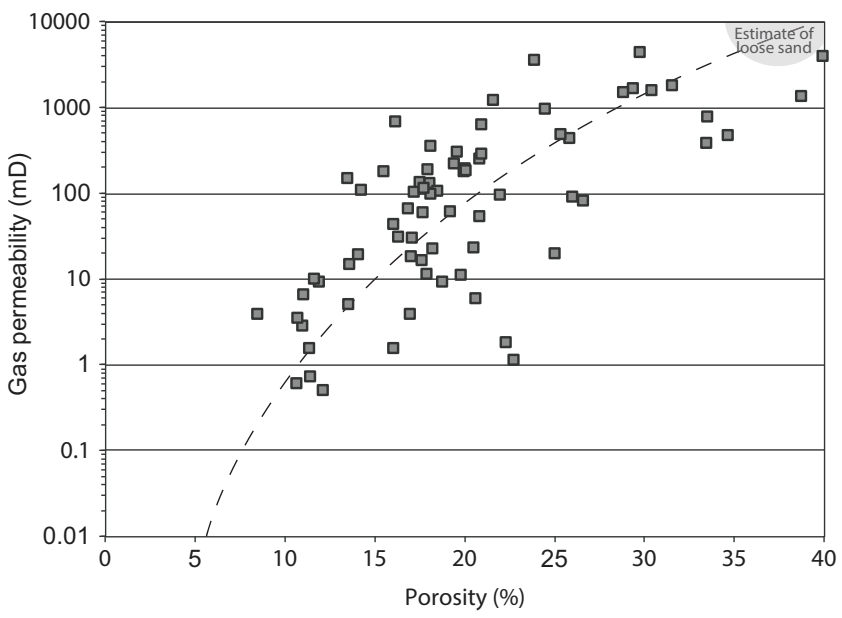

\begin{tabular}{|c|c|c|c|c|}
\hline$\square$ & Mixed grain sizes & - - Mixed grain sizes & Diagenetic cement & \\
\hline$\diamond$ & Very fine-grained & _ Very fine-grained & $\triangleright>10 \%$ Calcite, ankerite, dolomite & O $>10 \%$ Detrital clay \\
\hline$\bullet$ & Fine-grained & - - - Fine-grained & $\diamond>10 \%$ Siderite & O $>10 \%$ Clay clasts \\
\hline$\bullet$ & Medium-grained & — Medium-grained & $>>10 \%$ Anhydrite & \\
\hline$\bullet$ & Coarse-grained & - - - Coarse-grained & $\square>5 \%$ Quartz & \\
\hline \multirow[t]{2}{*}{$\Delta$} & Conglomerate & $\circlearrowright$ Thisted-2 well & $>5 \%$ Authigenic illite, chlorite & \\
\hline & & & $>5 \%$ Kaolinite & \\
\hline
\end{tabular}

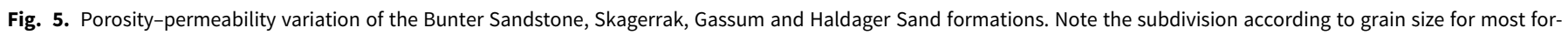

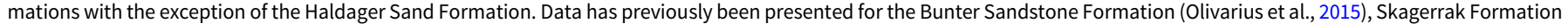

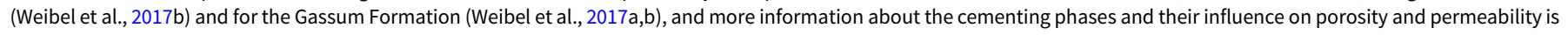
available from these references. Data for the Halder Sand Formation only is presented here.

The cementing phases comprise an average of $2-22 \%$ of the rock volume of the investigated wells, and the dominant cementing phases vary according to depositional environment and burial depth (Weibel et al., 2017b). Ankerite is the most abundant cement in deeply buried sandstones. In contrast, calcite or siderite are the dominant carbonate cement types in shallowly or intermediately buried sandstones. Whereas ankerite and calcite form poikilotopic pore-filling cement, siderite occurs as numerous tiny rhombs in the pore space and between cleavage planes in mica. Partial dissolution of calcite cement prior to enclosure in ankerite cement suggests that calcite may have been more common at shallow burial. Kaolinite occurs in both shallowly and deeply buried sandstones, where it typically fills oversize pores and the primary pores adjacent to partly dissolved feldspar grains or precipitates between the cleavage planes of mica, leading to expansion of its original size. Fibrous illite occurs in particular in deeply buried sandstones. Though the presence of mixed-layer illite/smectite is documented by X-ray diffraction, and supported by occasional honeycombtextured clay coatings, illite more commonly spreads out in the pores, suggesting illite replacement of kaolinitised mica or tangential detrital clays. Quartz cement increases in maximum abundance with increasing burial depth and is, together with ankerite cement, the most destructive cementing phase in the Gassum Formation (Figs 3 and 4). Completely intergrown quartz overgrowths occur in some of the deeply buried sandstones. Sutured grain-to-grain contact and stylolites develop along mica concentrations in some of the deeply buried 
sandstones (e.g. the Farsø-1 and Aars-1 cores). Thin Fe-rich chlorite coatings occur in estuarine-fluvial and shoreface sandstones from the forced regressive systems tract encountered in the Flyvbjerg-1 and Vedsted-1 wells. Irregularly distributed chlorite coatings intergrown with illite characterise sandstones in other forced regressive systems tracts (Farsø-1 and Børglum-1 wells).

Shallowly buried sandstones generally have higher porosity and permeability than deeply buried sandstones (Fig. 6). For the shallowly buried sandstones, the porosity-permeability trend varies with grain size, and therefore coarse-grained sandstones have a higher permeability at a specific porosity than the medium-, fineand very fine-grained sandstones (Figs 5 and 6). The exception is siderite-cemented sandstones, which at shallow burial have low permeability. In deeply buried sandstones, ankerite cement reduces both porosity and permeability, whereas illitic clays mainly reduce permeability, and quartz cement has a larger effect on porosity than permeability (Fig. 5; Weibel et al., 2017a,b).

\section{Haldager Sand Formation}

The Haldager Sand Formation comprises Middle Jurassic sandstones occurring in the Norwegian-Danish Basin. The formation generally has a thickness of less than $100 \mathrm{~m}$. The largest thicknesses of up to $c .175 \mathrm{~m}$ are present in the Sorgenfrei-Tornquist Zone, where the sand was deposited in shoreface and estuarine environments, which became intercalated with thin intervals of marine mud during rise in relative sea level. Towards the basin margins, the facies change to fluvial, lagoonal and lacustrine sediments (Nielsen, 2003). Cored intervals of the formation are present at variable depths of $0.4-2.5 \mathrm{~km}$ and have been buried to maximum depths of c.1.2-3.0 km prior to Neogene exhumation. The sediments came mainly from the north and east, with some supply from the south where sediments on the Ringkøbing-Fyn High were deeply eroded during the mid-Jurassic uplift event (Nielsen \& Japsen, 1991; Japsen \& Bidstrup, 1999; Michelsen et al., 2003; Nielsen, 2003; Japsen et al., 2007).

Sequence-stratigraphic subdivision of the formation indicates that some of the sandstone intervals have a regional extent within the distribution area of the formation (Nielsen, 2003). The Haldager Sand Formation consists of two to five continuous sandstone packages separated by thick claystone beds. The accumulated sandstone thickness is about $15-125 \mathrm{~m}$, and most of the gross sand is considered reservoir-quality sandstone (i.e. net sand).

The formation comprises light grey to greyish, fine- to mediumgrained sandstones that are in general well-sorted. In places, the sandstones are coarse to pebbly. Coal layers occurs locally. Siltstones and mudstones constitute a minor part of the formation. The sandstones are mainly quartz arenites and rare subarkoses. Small amounts of mica, rock fragments and heavy minerals are present in the sandstones, and locally also organic matter, intraclasts and detritral clays (Fig. 3). Heavy minerals are dominated by zircon, rutile and tourmaline.

The diagenetic alteration of the sandstones is limited, so the average content in each well of authigenic phases is $4-8 \%$ of the rock volume. Kaolinite is in general the most abundant phase; however, some samples contain higher amounts of pyrite, siderite, radiating clays or quartz overgrowths. Vermicular kaolinite has most often formed in relationship with partly altered K-feldspar and muscovite grains. Patchy pore-filling kaolinite is found in the deepest sandstones. The rare authigenic carbonates comprise patchy siderite in two wells, and a single sample contains patchy calcite cement. Incipient quartz overgrowths as mountains (according to the terminology of Weibel et al., 2010) have formed on quartz grains in the deepest buried well (Farsø-1) and they have locally merged to form thin quartz overgrowths (Fig. 4). Other authigenic phases, such as feldspar, anatase, iron-oxides/hydroxides and radiating clays, have locally precipitated in small amounts.

The reservoir quality of the Haldager Sand Formation is good in the majority of the sandstones. The mineralogical maturity is high and the abundance of cementing phases is low. Pervasive carbonate cement is not observed in the studied samples that are primarily from fluvio-deltaic sandstones, but it has been reported to occur locally in the shoreface sandstones (Nielsen \& Friis, 1985).

According to the results of the core analysis, the porosity of the sandstones is mainly $10-35 \%$ and with varying permeability of 1-2000 mD. However, the reservoir properties are presumably higher in the loose to weakly consolidated shallow part of the formation for which core analysis cannot be performed. The analysed samples are primarily from the Vedsted-1 and Farsø-1 wells. The formation is buried $0.8 \mathrm{~km}$ deeper in the Farsø- 1 well than in the Vedsted-1 well, which explains why the lowest average porosity and permeability occur here due to the higher degree of mechanical compaction. Furthermore, the sandstones in the Farsø-1 well contain more clay than those in the Vedsted-1 well, but this has only lowered the reservoir quality significantly when it occasionally is present as clay laminae and pore-filling clays.

\section{Parameters controlling the reservoir properties}

\section{Extent and thickness of reservoir}

The geometry of the sand bodies is crucial for reservoir quality. The extent and thickness of individual sandstone units define the geothermal water capacity and affect transmissibility. Detailed mapping is therefore necessary for correct positioning and completion of the production and injection wells.

The Bunter Sandstone Formation comprises aeolian sandstones of the Volpriehausen Member, which are considered to have a regional extent, and ephemeral fluvial deposits of the upper part of the Volpriehausen Member and Solling Member, which consists of more isolated sandstone bodies enclosed in lacustrine and playa mudstones (Clemmensen, 1985; Olivarius et al., 2017). The thickness of the individual sandstone intervals may be up to $30-50 \mathrm{~m}$.

The Skagerrak Formation has sandstone-dominated intervals with thicknesses in excess of $200 \mathrm{~m}$, where the braided stream deposits have aggraded. Unfortunately, large parts of the Skagerrak Formation are characterised by clayey sandstones of poor permeability. Well-sorted sandstones mainly occur in the central part of the basin and are here assumed to consist of elongated sandstone bodies.

Sandstone bodies of fluvio-estuarine and shoreface origin in the lower part of the Gassum Formation may extend over the entire Norwegian-Danish Basin, whereas the upper part of the formation is dominated by shoreface sandstones that pinch out into mudstones in the central part of the basin (Nielsen, 2003). Fluvial and estuarine deposits may be confined to channels, commonly eroded into the shoreface deposits. The Gassum Formation has 5 to 20 sandstone layers with thicknesses of 5-60 m, interbedded with mudstones.

Shoreface sandstones of the Haldager Sand Formation may have a regional extent (Nielsen, 2003), though with a smaller distribution than any of the Bunter Sandstone, Skagerrak and Gassum formations (Fig. 5). The Haldager Sand Formation typically has two to five continuous sandstones interbedded with mudstones. The combined thicknesses of 15-125 m of high-quality reservoir 

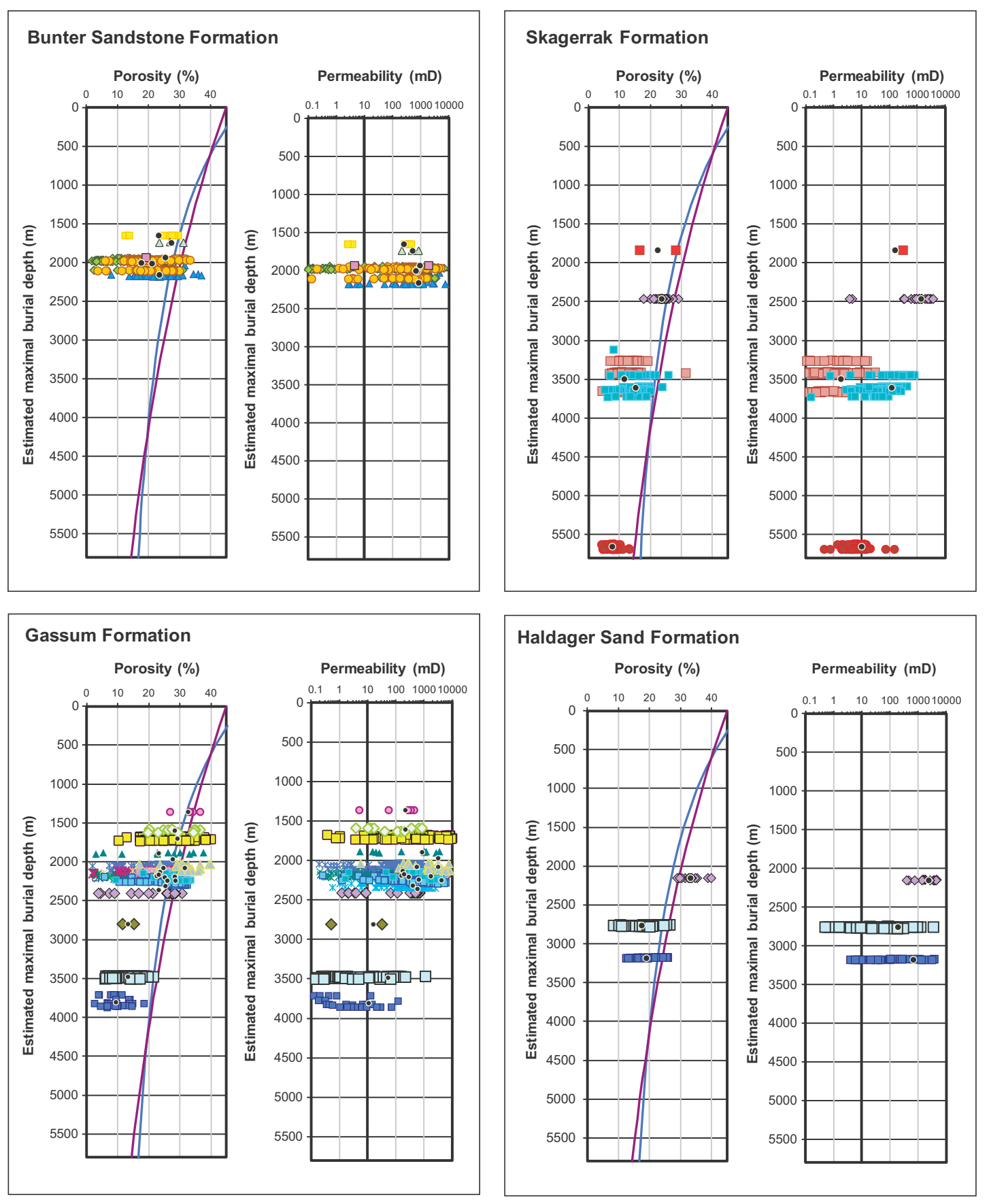

- Average

$\triangle$ Arnum-1

A Børglum-1

$\square$ Fars $\varnothing-1$

$\diamond$ Fjerritslev-2

$\diamond$ Frederikshavn-2

- Gassum-1

A Horsens-1

$\square$ Hønning-1

- Mors-1

$\square$ Rødby-1

Skagen-2

$\times$ Stenlille-1

* Stenlille-2

* Stenlille-4

* Stenlille-6

* Stenlille-10

$\square$ Stenlille-12

* Stenlille-13

* Stenlille-14

$\times$ Stenlille-15

$\square$ Stenlille-18

$\square$ Thisted-2

$\square$ Thisted-3

- Thisted-4

Tønder-3

$\diamond$ Tønder-4

$\Delta$ Tønder-5

$\diamond$ Vedsted-1

$\square$ Aars-1

Rammetal. (1997)

high porosity

Gluyas and Cade

(1997)

Perm. $=10 \mathrm{mD}$

Fig. 6. Porosity and permeability variation for the Bunter Sandstone, Skagerrak, Gassum and Haldager Sand formations with estimated maximum burial depth, which is presentday burial depth corrected for Neogene exhumation (Japsen \& Bidstrup, 1999; Japsen et al., 2007). The mechanical compaction curves from Gluyas \& Cade (1997) and Ramm et al. (1997) are shown for comparison on the porosity plots. An arbitrary threshold of $10 \mathrm{mD}$ is shown on the permeability plots for easy comparison. Origin of data similar to Figure 5.

sandstones make the Haldager Sand Formation one of the most promising targets for geothermal reservoirs, where present.

\section{Depositional environment}

The depositional environment controls the reservoir properties in several ways, first and foremost by defining the geometry of the deposited sand units, secondly by controlling the grain size and the abundance of detrital clay and thirdly by creating the perfect physiochemical conditions for mineral precipitation (i.e. resulting in early diagenetic cement).
The systematic change in relationship between porosity and permeability with grain size is evident irrespective of depositional environment. The permeability is higher for coarse- than for finegrained sandstones at the same porosity for both shoreface deposits of the Gassum Formation and ephemeral river deposits of the Bunter Sandstone Formation (Fig. 5; Olivarius et al., 2015; Weibel et al., 2017a). The average grain size has major influence on the permeability, since larger pore throats result in higher permeability. The grain-size effect on permeability has previously been documented for unconsolidated sand (Beard \& Weyl, 1973) and for sandstones (e.g. Ethier \& King, 1991; Nelson, 2009). 
Sandstones containing detrital clays, whether from the marine environment, lacustrine or playa lake, show reduced permeability compared to sandstones free of clays. Shoreface and fluvial sandstones from the Gassum Formation generally have higher permeability at specific porosities than the lagoonal and estuarine sandstones (Weibel et al., 2017a). Common detrital clay in the lagoonal and estuarine environment is an important permeabilityreducing factor. The exception is estuarine sandstones from the forced regressive system tract (Nielsen, 2003), where thin authigenic chlorite coatings are particularly common (Weibel et al., 2017a,b).

The early diagenetic physiochemical conditions are governed by the climate and depositional environment. The arid to semi-arid climate during deposition of the Bunter Sandstone and Skagerrak formations resulted in high evaporation and therefore local precipitation of caliche calcite and gypsum. Such pore-filling cements substantially reduce porosity and permeability in specific areas. However, even in sandstones with abundant cementing phases ( $>10 \%$ carbonate or anhydrite), the porosity and permeability may remain in the spectrum of a good reservoir rock, except if clay clasts or detrital clays are common (Fig. 5). The reason for this is that carbonate and anhydrite cement have a tendency to form patchy cement, which allows fluid flow around the cemented areas in the highly porous and permeable parts (Olivarius et al., 2015).

The Gassum and Haldager Sand formations were deposited under a humid climate where the high precipitation rate resulted in leached feldspar grains and common kaolinite precipitation (cf. Weibel et al., 2017a). Vegetation was more common during deposition in the humid climate, hence the organic matter created reducing conditions which promoted precipitation of siderite and pyrite. In particular, siderite cement can be pervasive and affect the permeability and porosity (Weibel et al., 2017a).

\section{Variation in cementing phases with burial depth}

Generally, the porosity and permeability decrease with increasing burial depth (Fig. 6). These trends reflect increasing abundances of cementing phases with burial depth in all formations. Though some early diagenetic phases may be replaced by more stable phases with burial, the porosity- and permeability reduction continues.

Evaporative processes were active in the arid to semi-arid climate that prevailed during deposition of the Bunter Sandstone Formation, hence gypsum, calcite and dolomite form patchy cement in fluvial sandstones (Weibel \& Friis, 2004; Olivarius et al., 2015). Anhydrite in the Bunter Sandstone Formation probably formed by recrystallisation of early precipitated gypsum, as documented by its displasive growth.

The Skagerrak Formation, being deposited in a similar arid to semi-arid climate, also has early carbonate cement, mainly of calcite and minor dolomite (Weibel 1998; Weibel et al., 2017b). Anhydrite cement is rare, probably because the sandstones were deposited by braided streams far from a playa lake. The carbonate-cemented sandstones typically have low porosity and permeability (Fig. 5). Pore-lining illitic clays become more important with increased burial depth and generally reduce permeability substantially (Weibel et al., 2017b). The influence of illite on permeability is illustrated by the group of sandstones having a comparable low permeability from the Thisted- 2 well, where sandstones are characterised by abundant coatings of fibrous illite (Fig. 5). Quartz cement can be more abundant with increased burial; however, in the Skagerrak Formation, quartz precipitation is commonly hindered due to thick clay coatings on the detrital grains (Weibel, 1998; Weibel et al., 2017b).
The shallowly buried sandstones in the Gassum Formation typically have few cementing phases, though locally pervasive kaolinite-, calcite- and siderite-cemented sandstones occur. Kaolinite cement seems to have only minor influence on porosity and permeability (Fig. 5). Siderite cement, consisting of numerous tiny crystals, mainly reduces permeability, whereas calcite cement reduces porosity and permeability equally (Fig. 5; Weibel et al., 2017a). Even though siderite and calcite cement may be common at shallow burial, this changes at deeper burial where ankerite is the most common carbonate cement (Weibel et al., 2017a,b). Ankerite forms a pore-filling cement similar to calcite and hence reduces both porosity and permeability. Similar to ankerite, the maximum abundance of quartz cement increases with burial. Therefore, for the Gassum Formation, the abundance of quartz cement according to burial depth may be predicted by diagenesis modelling (Nielsen et al., 2019; Olivarius et al., 2020). Sandstones from the forced regressive system tract (Nielsen, 2003) are characterised by early diagenetic chlorite coatings, which inhibit quartz overgrowths during increased burial and hence assist in preserving more of the porosity and permeability than would be expected according to burial depth.

Quartz and illite are important cementing phases at deep burial in both the Skagerrak and Gassum formations. Quartz cementation has not started in the investigated part of the Bunter Sandstone Formation, due to the shallow burial of the cored intervals. Quartz precipitation has just initiated in the Haldager Sand Formation as shown by the thin incipient quartz overgrowths (Fig. 4), though the abundance of authigenic quartz rarely exceeds $5 \%$. This, combined with a general coarse grain size and limited amounts of unstable minerals that could undergo diagenetic alterations during burial, means that the Haldager Sand Formation has excellent porosity and permeability.

\section{Formation water composition}

The formation water composition varies geographically and with burial depth (Laier, 2002, 2008; Holmslykke et al., 2019). Some of the compositional variations reflects depositional environment, association with underlying deposits and water expelled therefrom; others reflect mineral reactions occurring during burial.

The risk for scaling during operation of geothermal plants increases with the salinity of the formation water. A very high salinity characterises formation water from the Bunter Sandstone Formation in large parts of the North German Basin due to underlying Zechstein salt, interbedded halite-cemented intervals and overlying Röt salt (Holmslykke et al., 2019). The highly saline formation water, revealed among others in the Tønder area, constitutes an exploitation risk in the North German Basin (Olivarius et al., 2015; Hjuler et al., 2019).

Formation water generally increases in salinity with burial, whether from the Skagerrak or the Gassum formations, but does not reach concentrations that constitute exploitation risks (Laier 2002, 2008; Holmslykke et al., 2019). An increase with burial of the $\mathrm{K}^{+}$content in the formation water from the Gassum Formation probably reflects albitisation occurring in the sandstones (Weibel et al., 2017b; Holmslykke et al., 2019). This compositional change indicates that the risk of illite precipitation increases with burial.

\section{Geological guidelines and observations for geothermal exploitation in Denmark}

A conservative estimate of the Danish geothermal resource based on exploitation of known onshore reservoirs using current 
technology indicates a very large resource, amounting to more than three times the heat content in the Danish oil from the North Sea Basin. Utilisation of the resource requires district heating networks that are in place in Danish cities and the majority of larger towns. Geothermal energy thus has the potential to distribute heat to a large proportion of Danish households. The three existing geothermal plants in Denmark are producing from the Bunter Sandstone/ Skagerrak Formation and the Gassum Formation, and are only exploiting a minor fraction of the resource (Røgen et al., 2015; Poulsen et al., 2019). Based on the experience from these plants and from the concluded studies on reservoir distribution, temperature, diagenesis and simulated reservoir performance, as well as acknowledging the current economic-administrative regime, the following general guidelines for the utilisation of geothermal energy for district heating may be stated:

- At depths shallower than $c .800 \mathrm{~m}$, the temperature is generally too low (Vosgerau et al., 2016).

- At burial depths greater than $c .3000 \mathrm{~m}$ (in places corresponding to estimated maximum burial depths of 3500-4000 m), diagenetic alterations related to high-pressure, high-temperature conditions have in general reduced the porosity and permeability of the reservoir sandstones significantly for the Gassum Formation. For the Skagerrak Formation, estimated maximum burial depths greater than $c .3500 \mathrm{~m}$ and probably shallower may have reduced the permeability significantly due to illite precipitation. The Haldager Sand Formation has relatively high porosity and permeability at estimated maximum burial depth of $3200 \mathrm{~m}$.

- The salinity of the geothermal brines is related to burial depths and shows a fairly linear relation (Laier, 2002, 2008; Holmslykke et al., 2019).

- In parts of the North German Basin, the Bunter Sandstone Formation is halite-cemented and has a highly saline brine (Laier, 2002, 2008; Hjuler et al., 2019; Holmslykke et al., 2019), which may cause immediate precipitation of salt when the brine is produced due to pressure release and cooling. Geothermal plants in this area will have to consider filtering, down-hole dilution of the brine, or salt production as a by-product.

- More than one potential reservoir is present in many areas, which reduces the exploration risk and may prolong production profiles by application of more than one reservoir sandstone.

- The widely distributed Gassum and Bunter Sandstone/ Skagerrak formations are the most promising reservoirs in most parts of Denmark. The Haldager Sand Formation is highly promising in a specific area in northern Denmark.

- The more locally occurring Flyvbjerg and Frederikshavn formations as well as unnamed sandstones within the Fjerritslev Formation and the Lower Cretaceous units constitute local alternatives or supplements to the Gassum and Bunter Sandstone/Skagerrak formations.

- In general, a thickness of at least $15 \mathrm{~m}$ of clean sandstones (containing less than $30 \% \mathrm{mud} / \mathrm{shale}$ ) and a minimum transmissibility of $c .10$ Darcy metres is suggested as a conservative approach (Kristensen et al., 2016; Vosgerau et al., 2016).

\section{Summary and conclusions}

The Danish subsurface provides excellent opportunities for geothermal energy exploitation of which only a fraction is being exploited at present. The most prominent reservoirs comprise the Lower Triassic Bunter Sandstone Formation, the Triassic Skagerrak Formation, the Upper Triassic-Lower Jurassic Gassum Formation and the Middle Jurassic Haldager Sand Formation.

The well-established geological model of the NorwegianDanish Basin is based on seismic profiles, petrophysical logs and numerous cored intervals. Detailed petrography, together with porosity and permeability analyses of cored intervals, has allowed evaluation of the most prominent geothermal reservoirs in the Danish subsurface.

The reservoir quality of the Bunter Sandstone Formation is high, especially in the Volpriehausen Member since the aeolian deposits have a large lateral continuity, a fairly constant thickness, few cementing phases and are mostly clay-free. The shallow burial depth ensures reasonable porosity and permeability in most of the fluvial sandstones (mainly the Sollingen Member), despite a higher clay content and lesser degree of sorting. Furthermore, the lateral and vertical continuity are less for the Sollingen Member than for the Volpriehausen Member. Highly saline formation water in large parts of the North German Basin is one of the few drawbacks.

For the Skagerrak Formation, the best reservoir sandstones of braided stream deposits exist in the centre of the basin, since poorer sorted alluvial fan deposits dominate along the Fennoscandian Border Zone. However, the deepest burial and hence the highest abundances of cementing phases are coalescent with the centre of the basin. The porosity and permeability diminish relatively fast in the Skagerrak Formation with burial depth, compared with the Gassum Formation. The mineralogically immature composition promotes, among other authigenic phases, illite coatings, which in the Skagerrak Formation may be devastating for permeability.

The Gassum Formation sandstones are widespread in most of the Norwegian-Danish Basin with relatively good lateral continuity. The sediments become more sand-prone toward the northeast closer to the Fennoscandian sediment source area. The Gassum Formation exhibits fine reservoir properties relative to depth until estimated maximum burial depth of $3500 \mathrm{~m}$.

The Haldager Sand Formation has a more confined extent than the Gassum Formation, but thick sandstone intervals of high porosity and permeability show that it is an important geothermal reservoir in northern Denmark. The reservoir properties of the Haldager Sand Formation are in general better than those observed for the Gassum Formation sandstones, also with increasing burial depth. However, information from cored intervals is available only down to $3200 \mathrm{~m}$.

Relationships between reservoir properties, climate, depositional environment and burial depth have been established and are well understood. The mineralogical maturity of the original sediment defines in several ways the diagenetic changes and hence the porosity- and permeability reduction with burial depth. Therefore, extrapolation of reservoir properties with increased depth for the Bunter Sandstone and Haldager Sand formations can be made by comparison with the Skagerrak and Gassum formations, respectively.

Acknowledgement. This contribution is part of the project GEOTHERM ('Geothermal energy from sedimentary reservoirs - Removing obstacles for large scale utilization') (No. 6154-00011B) funded by the Innovation Fund Denmark (IFD). This paper is published with acceptance from the Geological Survey of Denmark and Greenland. 


\section{References}

American Petroleum Institute, 1998. API RP 40. Recommended practices for core analysis. Second edition. American Petroleum Institute (Washington, DC).

Beard, D.C. \& Weyl, P.K., 1973. Influence of texture on porosity and permeability of unconsolidated sand. American Association of Petroleum Geologists Bulletin 57, 349-369.

Bertelsen, F., 1980. Lithostratigraphy and depositional history of the Danish Triassic. Danmarks Geologiske Undersøgelse Serie B 4: 59 pp.

Britze, P. \& Japsen, P., 1991. Geological Map of Denmark 1:400.000. The Danish Basin. 'Top Zechstein' and the Triassic two-way traveltime and depth, thickness and interval velocity. Geological Survey of Denmark Map Series 31 .

Clemmensen, L.B., 1985. Desert sand plain and sabkha deposits from the Bunter Sandstone Formation (L. Triassic) at the northern margin of the German Basin. Geologische Rundschau 74, 519-536.

Ethier, V.G. \& King, H.R., 1991. Reservoir quality evaluation from visual attributes on rock surfaces: methods of estimation and classification from drill cuttings or cores. Bulletin of Canadian Petroleum Geology 39, 233-251.

Folk, R.L., 1966. A review of grain-size parameters. Sedimentology 6, 73-93.

Friis, H., 1987. Diagenesis of the Gassum Formation Rhaetian-Lower Jurassic, Danish Subbasin. Geological Survey of Denmark A 18: 41 pp.

Fuchs, S. \& Balling, N., 2016. Improving the temperature predictions of subsurface thermal models by using high-quality input data. Part 1: Uncertainty analysis of the thermal-conductivity parameterization. Geothermics 64: 42-54.

Fuchs, S., Balling, N. \& Förster, A., 2015. Calculation of thermal conductivity, thermal diffusivity and specific heat capacity of sedimentary rocks using petrophysical well logs. Geophysical Journal International 203(3): 1977-2000.

Fuchs, S., Balling, N. \& Mathiesen, A., 2020. Deep basin temperature and heatflow field in Denmark: new insights from borehole analysis and 3D geothermal modelling. Geothermics 83, 101722.

Geluk, M.C. \& Rohling, H.G., 1997. High-resolution sequence stratigraphy of the Lower Triassic 'Buntsandstein' in the Netherlands and northwestern Germany. Geologie en Mijnbouw 76: 227-246.

Gluyas, J. \& Cade, C.A., 1997. Prediction of porosity in compacted sands. In: Kupecz, J.A., Gluyas, J. \& Block, S. (eds): Reservoir quality prediction in sandstones and carbonates. American Association of Petroleum Geologists Memoir 69: 19-28.

Hamberg, L. \& Nielsen, L.H., 2000. Shingled, sharp-based shoreface sandstones: depositional response to stepwise forced regression in a shallow basin, Upper Triassic Gassum Formation, Denmark. In: D. Hunt \& R. Gawthorpe (eds): Sedimentary responses to forced regressions. Geological Society of London, Special Publication 172: 69-89.

Hjuler, M.L., Olivarius, M., Boldreel, L.O., Kristensen, L., Laier, T., Mathiesen, A., Nielsen, C.M. \& Nielsen, L.H., 2019. Multidisciplinary approach to assess geothermal potential, Tønder area, North German Basin. Geothermics 78: 211-223.

Holmslykke, H.D., Schovsbo, N.H., Kristensen, L., Weibel, R. \& Nielsen, L.H., 2019. Brine types in Danish Deep onshore sandstone reservoirs exploited for geothermal energy. Geological Survey of Denmark and Greenland Bulletin 42.

Japsen, P. \& Bidstrup, T., 1999. Quantification of late Cenozoic erosion in Denmark based on sonic data and basin modelling. Bulletin of the Geological Society of Denmark 46: 79-99.

Japsen, P. \& Langtofte, C., 1991. Geological map of Denmark 1:400.000. The Danish Basin. 'Top Triassic' and the Jurassic - Lower Cretaceous, two-way traveltime and depth, thickness and interval velocity. Geological Survey of Denmark Map Series 30.

Japsen, P., Green, P.F., Nielsen, L.H., Rasmussen, E.S. \& Bidstrup, T., 2007. Mesozoic-Cenozoic exhumation events in the eastern North Sea Basin: a multi-disciplinary study based on palaeothermal, palaeoburial, stratigraphic and seismic data. Basin Research 19: 451-490.

Kazmierczak, J., Marty, N., Holmslykke, H.D. \& Weibel, R., 2019. The risk of scaling and corrosion prediction from formation water composition for Danish geothermal plants. GEOTHERM - Geothermal energy from sedimentary reservoirs - Removing obstables for large scale utilization. Innovation Fun Denmar: project 6154-00011B (Final report in WP3). Geological Survey of Denmark and Greenland Bulletin 2019/24: 53 pp.
Kristensen, L., Hjuler, M.L., Frykman, P., Olivarius, M., Weibel, R., Nielsen, L.H. \& Mathiesen, A., 2016. Pre-drilling assessments of average porosity and permeability in the geothermal reservoirs of the Danish area. Geothermal Energy 4(6): 1-27.

Laier, T., 2002. Vurdering af udfældningsrisici ved geotermisk produktion fra Margretheholmboringen MAH-1A. Beregning af mætningsindeks for mineraler i saltvand fra Danmarks dybere undergrund. Danmarks og Grønlands Geologiske Undersøgelser Rapport 2002/95: 48 pp.

Laier, T., 2008. Chemistry of Danish saline formation waters relevant for core fluid experiments: fluid chemistry data for lab experiments related to $\mathrm{CO} 2$ storage in deep aquifers. Geological Survey of Denmark and Greenland Report 2008/48: $10 \mathrm{pp}$.

Laier, T. \& Nielsen, B.L., 1989. Cementing halite in Triassic Bunter Sandstone (Tønder, southwest Denmark) as a result of hyperfiltration of brines. Chemical Geology 76, 353-363.

Larsen, G., 1966. Rhaetic - Jurassic - Lower Cretaceous sediments in the Danish Embayment (a heavy-mineral study). Geological Survey of Denmark, II Row, 91: $127 \mathrm{pp}$.

Liboriussen, J., Ashton, P. \& Tygesen, T., 1987. The tectonic evolution of the Fennoscandian Border Zone in Denmark. Techtonophysics 137: 21-29.

Longiaru, S., 1987. Visual comparators for estimating the degree of sorting from plane and thin sections. Journal of Sedimentary Research 57: 791-794.

Mathiesen, A., Nielsen, L.H. \& Bidstrup, T., 2010. Identification of the potential geothermal reservoirs in Denmark. Geological Survey of Denmark and Greenland Bulletin 20: 19-22.

McBride, E.F., 1963. A classification of common sandstones. Journal of Sedimentary Research 33: 664-669.

Michelsen, O. \& Clausen, O.R., 2002. Detailed stratigraphic subdivision and regional correlation of the southern Danish Triassic succession. Marine and Petroleum Geology 19, 563-587.

Michelsen, O. \& Nielsen, L.H., 1991. Well records on the Phanerozoic stratigraphy in the Fennoscandian Border Zone, Denmark. Hans-1, Sæby-1, and Terne-1 wells. Danmarks Geologiske Undersøgelse, Ser. A 29: 39 pp.

Michelsen, O. \& Nielsen, L.H., 1993. Structural development of the Fennoscandian Border Zone, offshore Denmark. Marine and Petroleum Geology 10: 124-134.

Michelsen, O., Nielsen, L.H., Johannessen, P., Andsbjerg, J. \& Surlyk, F., 2003. Jurassic lithostratigraphy and stratigraphic development onshore and offshore Denmark. In: Ineson, J.R. \& Surlyk, F. (eds): The Jurassic of Denmark and Greenland. Geological Survey of Denmark and Greenland Bulletin 1: 147-216.

Nielsen, B.L. \& Friis, H., 1985. Diagenesis of Middle Jurassic Haldager Sand Formation sandstone in the Danish Subbasin, north Jutland. Bulletin of Geological Society of Denmark 33, 273-285.

Nelson, P.H., 2009. Pore-throat sizes in sandstones, tight sandstones, and shales. American Association of Petroleum Geologists Memoir 93: 329-340.

Nielsen, L.H., 2003. Late Triassic - Jurassic development of the Danish Basin and Fennoscandian Border Zone, Southern Scandinavia. In: Ineson, J.R. \& Surlyk, F. (eds): The Jurassic of Denmark and Greenland. Geological Survey of Denmark and Greenland Bulletin 1: 459-526.

Nielsen, L.H. \& Japsen, P., 1991. Deep wells in Denmark 1935-1990. Lithostratigraphic subdivision. Danmarks Geologiske Undersøgelse, Ser. A 31: 179 pp.

Nielsen, L.H., Mathiesen, A. \& Bidstrup, T., 2004. Geothermal energy in Denmark. Review of Survey activities 2003. Geological Survey of Denmark and Greenland Bulletin 4: 17-20.

Nielsen, M.T., Olivarius, M., Weibel, R., Mathiesen A., Tremosa, J., Bonnell, L. \& Nielsen, L.H., 2019. Geothermal reservoir quality prediction from diagenesis modelling. European Geothermal Congress 11-14 June 2019, The Hague, the Netherlands. Conference proceedings.

Olivarius, M. \& Nielsen, L.H., 2016. Triassic paleogeography of the greater eastern Norwegian-Danish Basin: constraints from provenance analysis of the Skagerrak Formation. Marine and Petroleum Geology 69: 168-182.

Olivarius, M., Weibel, R., Hjuler, M.L., Kristensen, L., Mathiesen, A., Nielsen, L.H. \& Kjøller, C. 2015. Diagenetic effects on porosity-permeability relationships in red beds of the Lower Triassic Bunter Sandstone Formation in the North German Basin. Sedimentary Geology 321: 139-153. 
Olivarius, M., Weibel, R., Friis, H., Boldreel, L.O., Keulen, N. \& Thomsen, T.B., 2017. Provenance of the Lower Triassic Bunter Sandstone Formation: implications for distribution and architecture of aeolian vs. fluvial reservoirs in the North German Basin. Basin Research 29 (Suppl. 1): 113-130.

Olivarius, M., Laier, T., Knudsen, C., Clausen, L.F., Malkki, S.N., Thomsen, T.B., Serre, S.H., Kristensen, L., Willumsen, M.E., Nielsen, L.H. \& Roos, P., 2019. Occurrence and source of radioactive lead in geothermal formation water, Denmark. European Geothermal Congress, 11-14 June 2019, The Hague, the Netherlands. Conference proceedings.

Olivarius, M., Tremosa, J., Mathiesen, A., Weibel, R., Dalgaard, M.T., Nielsen, L.H., Whitehouse, M.J., Bonnell, L.M. \& Lander, R.H., 2020. Estimation of geothermal reservoir quality by diagenesis modelling of the Gassum Formation sandstones. Nordic Geological Winter Meeting, 8-20 January 2020, Oslo, Norway. Abstract.

Olsen, H., 1988. Sandy braidplan deposits from the Triassic Skagerrak Formation in the Thisted-2 well, Denmark. Geological Survey of Denmark, Ser. B 11: 26 pp.

Pedersen, G.K. \& Andersen, P.R., 1980. Depositional environments, diagenetic history and source areas of some Bunter Sandstones in northern Jutland. Geological Survey of Denmark, Yearbook 1979: 69-93.

Poulsen, S.E., Balling, N., Bording, T.S., Mathiesen, A. \& Nielsen, S.B., 2017. Inverse geothermal modelling applied to Danish sedimentary basins. Geophysical Journal International 211(1): 188-206.

Poulsen, S.E., Bjørn, H., Mathiesen, A., Nielsen, L.H., Vosgerau, H., Vangkilde-Pedersen, T., Ditlefsen, C. \& Røgen, B., 2019. Geothermal energy use. Country update for Denmark. European Geothermal Congress, 11-14 June 2019, The Hague, the Netherlands. Conference proceedings.

Priisholm, S., Nielsen, B.L. \& Haslund, O., 1987. Fines migration, blocking, and clay swelling of potential geothermal sandstone reservoir, Denmark. SPEFE 2: 168-178.

Ramm, M., Forsberg, A.W. \& Jahren, J.S., 1997. Porosity-depth trends in deeply buried Upper Jurassic reservoirs in the Norwegian Central Graben: an example of porosity preservation beneath the normal economic basement by grain-coating microquartz. In: Kupecz, J.A., Gluyas, J. \& Bloch, S. (eds): Reservoir quality prediction in sandstones and carbonates. AAPG Memoir 69: 177-199.

Røgen, B., Ditlefsen, C., Vangkilde-Pedersen, T., Nielsen, L.H. \& Mahler, A., 2015. Geothermal energy use, 2015. Country update for Denmark. World Geothermal Congress, 19-25 April 2015, Melbourne, Australia. Paper 01079.
Vejboek, O.V., 1989. Effects of asthenospheric heat flow in basin modelling exemplified with the Danish Basin. Earth and Planetary Science Letters 95: 97-114.

Vosgerau, H., Mathiesen, A., Andersen, M.S., Boldreel, L.O., Hjuler, M.L., Kamla, E., Kristensen, L., Pedersen, K.B., Pjetursson, B. \& Nielsen, L.H., 2016. A WebGis portal for exploration of deep geothermal energy based on geological and geophysical data. Geological Survey of Denmark and Greenland Bulletin 35: 23-26.

Vosgerau, H., Gregersen, U., Kristensen, L., Lindström, S., Mathiesen, A., Nielsen, C.M., Olivarius, M. \& Nielsen, L.H., 2017. Towards a geothermal exploration well in the Gassum Formation in Copenhagen. Review of Survey activities 2016. Geological Survey of Denmark and Greenland Bulletin 38: 29-32.

Weibel, $R$. 1998. Diagenesis in oxidising and locally reducing conditions - an example from the Triassic Skagerrak Formation, Denmark. Sedimentary Geology 121: 259-276.

Weibel, R., 1999. Effects of burial on the clay assemblages in the Triassic Skagerrak Formation, Denmark. Clay Minerals 34: 619-635.

Weibel, R. \& Friis, H., 2004. Opaque minerals as keys for distinguishing oxidising and reducing diagenetic conditions in the Lower Triassic Bunter Sandstone, North German Basin. Sedimentary Geology 169: 129-149.

Weibel, R. \& Groberty, B., 1999. Pseudomorphous transformation of geothite needles into hematite in sediments of the Triassic Skagerrak Formation, Denmark. Clay Minerals 34: 657-661.

Weibel, R., Friis, H., Kazerouni, A.M., Svendsen, J.B., Stokkendahl, J. \& Poulsen, M.L., 2010. Development of early diagenetic silica and quartz morphologies: examples from the Siri Canyon, Danish North Sea. Sedimentary Geology 228: 151-170.

Weibel, R., Olivarius, M., Kristensen, L., Friis, H., Hjuler, M.L., Kjøller, C., Mathiesen, A. \& Nielsen, L.H., 2017a. Predicting permeability of low enthalpy geothermal reservoirs: examples from the Upper Triassic-Lower Jurassic Gassum Formation, Norwegian-Danish Basin. Geothermics 65: 135-157.

Weibel, R., Olivarius, M., Friis, H., Kristensen, L., Hjuler, M.L., Kjøller, C., Pedersen, P.K., Boyce, A., Mathiesen, A. \& Nielsen, L.H., 2017b. The influence of climate on early and burial diagenesis in Triassic and Jurassic sandstones from the Norwegian-Danish Basin. The Depositional Record 3(1): 60-91.

Wentworth, C. K. 1922. A scale of grade and class terms for clastic sediments. Journal of Geology 5: 377-392. 